\title{
Research on the Logical Growth Point of Modern Ideological and Political Education
}

\author{
Marxism Hominology*
}

\author{
Xueshou Huang \\ Zhuhai College of Jilin University \\ Zhuhai, China
}

\author{
Mingchao Li \\ Zhuhai College of Jilin University \\ Zhuhai, China
}

\begin{abstract}
The rise of Marxist Hominology and the replacement of the paradigm of humanism have broadened the horizons of modern ideological and political education study. This article is guided by Marxist philosophy and historical materialism. It focuses on the characteristics of human existence, the generation, nature and value of ideological and political education and analyzes the historical practice of the Chinese Communist Party on the free and comprehensive development of human beings. It has concretely demonstrated the rationality and inevitability of "human existence and development" as the ontological dimension of ideological and political education, and put forward the prospects of all-round development of human beings in new era of socialism.
\end{abstract}

Keywords-human existence and development; ideological and political education

\section{INTRODUCTION}

Ideological and political education is a science. As an educational activity that focuses on inheriting and reforming ideas, political consciousness, and moral culture, "it is a special expression of human needs and life activities"[1]. It is constructed on the basis of "man's survival needs". The start and end points of it are both "people". The problem of people is the most intrinsic and essential issue of ideological and political education. As we all know, any type of education has its own theoretical origins and foundations. Ideological and political education also has its own basis to generate, exist, and develop. The rise of Marxist Hominology and the replacement of the paradigm of humanism have broadened the horizons for the study of modern ideological and political education. Only from the perspective of "the existence and development of people" and the internal relation between "existence of ideological and political education and the survival of human beings" can we truly understand the basis of ideological and political education.

*Source of the project: This is the phased research achievement of the project "The Value of Ideological and Political Education for Innovative Talents Cultivation in Universities" which is the Youth Innovation Talents Project (Humanities and Social Sciences) in the Guangdong colleges provincial key platforms and major scientific research projects in 2017.

\section{The Human NATURE Basis OF MOdERn IDEOLOGICAL AND POLITICAL EDUCATION}

The main purpose of ideological and political education is to inherit and transform people's ideas, political awareness, and moral values. Ideological and political education can be understood in this way is based on a philosophical basis: Man's survival is doomed not only to pursue material satisfaction, but also to pursue spiritual satisfaction. That is to say, human beings doom to explore infinite meaning and ultimate value. The emergence, change, and development of any form of human education have their own profound human nature. Marx regards human development as a kind of realistic human activity. He believes that the starting point of human development is the reality, which is the sum of all social relations. "[2]

The "modern ideological and political education" is not simply a "modern" addition to "ideological and political education." As the theoretical foundation and guiding ideology of ideological and political education, Marxism has the top proposition of realizing man's all-round and free development. This means that the function and value of modern ideological and political education are to meet the needs of human existence and development in modern society. The view of human nature in Marxism regards human existence as a trinity of the nature, sociality, and spirituality of human. These human characteristics also inevitably lead to the natural, social, and spiritual needs of human existence. The difference between modern ideological and political education and traditional ideological and political education is that modern ideological and political education is based on these human characteristics to help the existence and development of human in reality.

Because there are natural, social and spiritual needs of human existence, modern ideological and political education must take these into account to gain practical achievements. As the advanced weapon and effective means for the proletarian party to do ideological work, modern ideological and political education must attach importance to people's social and spiritual needs, and truly regard them as the starting point and ending result of its work. Only in this way can the rationality of the existence of modern ideological and political education be ensured. 


\section{THE HISTORICAL PRACTICAL EXPERIENCE OF THE COMMUNIST PARTY OF CHINA ON HUMAN EXISTENCE AND DEVELOPMENT}

The report of the Nineteenth National Congress of the Communist Party of China proposed to build socialist market economy, socialist democracy, advanced socialist culture, a harmonious socialist society, and socialist ecological civilization, to promote the all-round development of people, to gradually realize the common prosperity, and to construct a prosperous, democratic, civilized and harmonious modern socialist country. The scientific proposition of promoting people's comprehensive development is not only the inheritance and innovation by Chinese Communists on the theory of social progress and comprehensive human development in Marxism in the long-term period of revolution, construction and reform for China, but also a grand goal that Chinese people will strive to achieve under the leadership of the party in new historical conditions. It is an important idea based on the core values of socialism and of great significance and far-reaching impact.

The ideological and political work of the Chinese Communist Party has always been focused on solving ideological issues from people's basic needs. The first generation of leadership groups represented by Mao Zedong discussed the concept of human comprehensive development, deeply analyzed the objectives, paths, and other aspects of human comprehensive development, and made" three equal education", "red and special" and others as the specific goals. These are the specifics of Marxist human comprehensive development theory in China. The second-generation central leadership group represented by Deng Xiaoping proposed new goals for improving the quality of the entire society and cultivating new talents with "four qualities" based on changes in the theme of times and the practice of reform and opening up, pointed out that common prosperity was the realistic basis and value orientation for comprehensive human development, believed that people's comprehensive development could be promoted only after the well-off society was fully constructed in China. After the Third Plenary Session of the 13th CPC Central Committee, the third-generation leadership of the CCP analyzed changes in the world situation, national conditions, and people's sentiments, proposed that the comprehensive development of man is the essential requirement of the new socialist society in light of the specific practice of the socialist cause with Chinese characteristics, pointed out that man's comprehensive development and economic social development are two historical processes that are never-ending, put forward the specific goals of the comprehensive development of human beings in the concrete process of the development of socialism with Chinese characteristics. Since the 16th CPC National Congress, the CPC Central Committee has seized important strategic opportunities, guided by the scientific outlook on development, adhered to the principle of being people-centered, and believed that building a harmonious socialist society was an inherent requirement for the comprehensive development of man, systematically elaborated the relationship between the concept of scientific development and the comprehensive development of human.
Since the party's 18th National Congress, the Party Central Committee with Comrade Xi Jinping as the core has created a new realm of Marxism in China, vividly interpreted the idea of comprehensive human development, which condenses the wisdom of the entire party and reflects the fundamental purpose of the Chinese Communist Party to serve the people wholeheartedly, reflects the materialist conception of history that people are the fundamental force for the development. It is of great and far-reaching significance for realizing the goal of "two hundred years" and the great rejuvenation of the Chinese nation and the promotion of human liberation.

In fact, more than 90 years since the founding of the Communist Party of China, the Chinese Communist Party has always adhered to the people-centered principle, made realizing human liberation and freedom, promoting people's comprehensive development as its unrelenting pursuit, tested Marxism Hominology, and confirmed that human existence is a natural, social and spiritual existence, and it is also a historical structural relationship. To inspect and analyze the historical trajectory of the Communist Party of China on the evolution of man's comprehensive development thinking, and to sum up its experience and lessons, have important theoretical significance, and has practical value for fully constructing the well-off society and realizing man's free and comprehensive development.

\section{THE NEW REQUIREMENTS FOR THE VALUE OF} IDEOLOGICAL AND POLITICAL EDUCATION IN THE NEW ERA

In the 21st century, with the economic globalization, development of China's socialist market economy, collision of multicultural values and the publicity of people's subjective awareness, the traditional values of ideological and political education that emphasize oneness "political instrumentality" appear to be outdated. In order to adapt to the development of the new era, the idea of ideological and political education must be innovated, and this innovation must be reflected in the values of ideological and political education, so as to enhance the attractiveness, appeal and effectiveness of ideological and political education. Since Marxism is the theoretical foundation and guiding ideology of ideological and political education, ideological and political education is to realize its value starting point, core value and humanistic implication under the guidance of Marxist Hominology. This is undoubtedly also the fundamental requirement of "human existence and development" as the logical growth point of ideological and political education.

The existence of people in reality: the starting point of the development of the ideological and political education value in the new era. The direct object of ideological and political education is people. Therefore, to realize the contemporary development of the value of ideological and political education, we must take "the existence of realistic people" as the starting point. It is well-known that the issue of real individual existence and human development is the focus of Marxist Hominology. Starting from the "real people" led to all the thoughts about people in Marxism. From the reality stipulation of the existence of human beings by Marxist classic writers, as a form of life practice of real people, the emergence and existence of ideological and political education activities are 
not accidental. They are the objective needs of human existence and development and the inevitable result of history. We must realize that the value of ideological and political education is based on the actual individual existence. Its goal is to realize individual's existing value, and this value will definitely set a clear boundary for the function and purpose of modern ideological and political education. Its original value is to meet the needs of the comprehensive development of individuals who have made up the society.

Meet the diverse needs of people: the core of the development of ideological and political education value in the new era. As a special and universal educational practice activity, ideological and political education not only teaches ideological concepts, moral knowledge, and behavior norms, but also improves people's spirit and helps to realize people's values. In this education practice, both teachers and learners are unities of spirit and bodies and have their own rich material and spiritual needs. Ideological and political education can only reflect its own value by satisfying people's spiritual needs and the diverse needs of human existence and development. This requires ideological and political education to face people's needs in practical work, so as to enhance the pertinence and effectiveness of it. Therefore, as a cultural form of human beings, whether ideological and political education can succeed in shaping modern moral personality and inheriting ideology and culture depends on whether it can truly satisfy people's diverse needs.

Promoting People's Comprehensive Development is The Direction of the Development of Ideological and Political Education Value in the New Era. Realizing the free and comprehensive development of mankind is the ultimate value pursuit of Marxist Hominology, and it is also the essence of our current construction and development of socialism with Chinese characteristics. Marx pointed out that the entire process of ideological and political education is in fact a process of elevating the value of people. For this reason, the contemporary development of the value of ideological and political education should be based on the promotion of people's comprehensive development. Marxists have always attached importance to the special role of ideological and political education in the process of realizing man's comprehensive development. As an integral part of the socialist cause with Chinese characteristics and a kind of social practice that nurtures and shapes people, ideological and political education has made promoting and realizing people's comprehensive development as its fundamental goal and value orientation.

In the new era, as the direct education for people's ideas, ideological and political education must take effective measures to actively promote the healthy development of people's thoughts and spirits, and make itself become human's spiritual habitats to play an invisible power catalytic effect on people's lives. As pointed out by Comrade Xi Jinping, ideological and political work "must adhere to the peoplecentered development strategy. This is the fundamental position of Marxist political economics." At the moment, the development of China's socialist market economy and its unique vitality and tolerance of cultural diversity provide the greatest possibility for the formation of independent personality. When the value of modern ideological and political education fully embodies the respect for individual existence, and satisfies the various needs of people, it will undoubtedly promote the comprehensive and harmonious development of man.

In the long-term revolution, construction, and reform process, the Chinese Communist Party has explored a unique path of firstly realizing the political emancipation of Chinese people and then advancing people's comprehensive development. This is a great contribution to the Marxist human development theory. The Communist Party of China once fell into the dilemma between economic development and human development, material demand and human spiritual aspiration, collectivism and human freedom. These problems have been resolved well later by the party. Today, in the globalized environment and in the historical process of promoting the great cause of socialism with Chinese characteristics, the practical value of the comprehensive development of human beings has further manifested. This is the call for social progress and is an inevitable requirement for the full-scale construction of a well-off society in China. Therefore, to explore the law and basic experience of man's comprehensive development and reveal its epochal value are of great theoretical value and practical significance for improving the moral quality of citizens and ultimately achieving the great rejuvenation of the Chinese nation.

\section{CONCLUSION}

The comprehensive development of mankind is the core content of Marxist theory. It is the Chinese Communist Party's and the Chinese people's long-cherished wish and untiring pursuit. It is also the most critical, deepest, and most difficult work in the modernization of socialism with Chinese characteristics. We must proceed from the social productivity, accelerate the development of the economy, promote the modernization of socialism with Chinese characteristics, rapidly strengthen the country's overall power, continuously improve people's living standards and cultural levels, work hard together, unremittingly pursue and actively practice to achieve this goal.

\section{REFERENCES}

[1] Zhang Yaocan, Xu Zhiyuan: "Discussion on the Subject of Modern Ideological and Political Education", Hubei People's Publishing House, 2003, pp. 360. 张耀灿、徐志远: 《现代思想政治教育学科论》, 湖 北人民出版社 2003 年版，第 360 页。

[2] "Selected Works of Marx and Engels", Vol. 1, People's Publishing House, 1995, pp. 56. 《马克思恩格斯选集》第 1 卷, 人民出版社 1995 年版, 第 56 页。 